\title{
Feeding Efficiency of Six Beetle Species against Mustard Aphid, Lipaphis erysimi (Kalt.) in Uttarakhand, India
}

\author{
Sundar Pal* and Jitendra Bhatt
}

Department of Plant protection, DBS College of Agriculture and Allied Sciences, Selaqui, Deharadun, Uttrakhand-248001, India

*Corresponding author

\section{A B S T R A C T}

\begin{tabular}{|l|}
\hline Ke y w or d s \\
$\begin{array}{l}\text { Feeding efficiency, } \\
\text { Beetle, Mustard aphid, } \\
\text { Lipaphis erysimi }\end{array}$ \\
\hline Article Info \\
\hline $\begin{array}{l}\text { Accepted: } \\
16 \text { March } 2018 \\
\text { Available Online: } \\
10 \text { April } 2018\end{array}$ \\
\hline
\end{tabular}

Keywords

Feeding efficiency, Beetle, Mustard aphid, Lipaphis erysimi

\section{Introduction}

Coccinellids are the member of family Coccinellidae and are amongst the most familiar beetles known variously as ladybirds. Numerous species of coccinellids are predatory against Hemipteran insect pests such as aphids, mealy bugs and scale insects, as well as thrips (Thysonoptera) and mites (Acarina) in all parts of the world (Hawkeswood, 1987; Majerus, 1994). The family coccinellidae comprises of about 5,200 described species worldwide (Hawkeswood, 1987) of which 400 species of coccinellids from Indian sub-region, which include the erstwhile state of Uttar Pradesh and Uttarakhand (Poorani, 2002). Joshi and
Sharma (2008) have reported 31 species of Ladybeetles with 19 new records from district Haridwar, India. Recently, Sharma and Joshi (2010) have also reported 25 species of ladybeetles with 14 new records from district Dehradun, India. The aphid is one of the most destructive pests and its distribution is worldwide. The aphids also act as vectors for numerous plant viruses. Chemical control method are largely effective and provide quick relief from majority of aphids, but at the same time cause several adverse effects, like resistance to pesticides, pest resurgence, secondary pests outbreaks, killing non-target animals, increasing susceptibility of crops, environmental degradation, bioaccumulation and health hazard to humans and cattle due to 
environmental and ecological concerns, there is a need to developed alternative insect control. Omkar (1999) reported ten coccinellid predators species from an extensive survey of local agricultural fields in U.P. The use of natural enemies of pest themselves by man to manage population of insect pest is known as Biological Control. The first spectacular achievement in the field of biological control was the use of a coccinellid beetle, Rodolia cardinalis Muls from Australia into California in 1888 for controlling cottony cushion scale, Icerya purchasi Mask, which threatened the citrus industry (Riley, 1893 and Majerus, 1994). Therefore, the objective of the present study is investigating the effect of different species of ladybird on mustard aphid.

\section{Materials and Methods}

The study was carried out in the Departmental laboratory of the institute during 2016-17. Feeding potential of adults and instars of grubs of six species of ladybird beetle on mustard aphid was assessed in laboratory condition. The species are Coccinella septempuctata (Linn.), Cheilomenus sexmaculata (Fab.), Hippodamia convergenson (Zoeze), Anegleis cardoni (Weise), Micraspis allardi (Mulsant) and Illeis cincta (Fab.). The species collected from local agriculture crops and reared in the mustard aphid, Lipaphis erysimi. The experiment was carried in Petri dishes $(15 \times 2 \mathrm{~cm})$ with three replicates, having moistened filter paper at the bottom to avoid desiccation and maintaining optimum humidity. For each species, one pair of grub of every instar stage and an adult was released with the help of brush, in each replicate. The fresh aphids thrashing in separate Petri dish with the and finally transferred of counted aphid in Petri dish. For each species a total of 20,75, 150, 200 and 300 fresh aphids for $1^{\text {st }}, 2^{\text {nd }}, 3^{\text {rd }}, 4^{\text {th }}$ instar grub and adult, respectively, were released daily in each replicate. The aphids were collected from terminal twigs of mustard plants grown in the field. The experiment was run for 6 hours in day time and consumption pattern data was recorded by counting numbers of available aphids in a replicate daily. The experiment terminated after the change in the stadium stage of each instar and in adults only for five days because. Consumption was calculated as:

Consumption $=$ Number of release aphidsNumber of remaining aphids

\section{Results and Discussion}

Feeding potential of Coccinella species against mustard aphids.

Feeding potential of $C$. septumpunctata (Linn.) on mustard aphid L. erysimi (Kalt.)

The first instar larvae consumed $3.00 \pm 0.58$ aphids/pair in the first day, while during the second and third day the consumption was only $4.00 \pm 0.58$ and $6.00 \pm 0.58$ aphids/pair. The first instar grubs consumed $4.33 \pm 0.58$ aphids/pair. The second instar grub consumed $24.00 \pm 3.47, \quad 27.00 \pm 1.53, \quad 34.33 \pm 1.20, \quad$ and $34.33 \pm 1.45$ aphids/pair at $1^{\text {st }}, 2^{\text {nd }}, 3^{\text {rd }}$ and $4^{\text {th }}$ days of life, respectively. Third instar grubs survive five days and consumption increased continuously from $1^{\text {st }}$ to $5^{\text {th }}$ day of life (Table1). The range of consumption of pray at this stage was noticed $101.53 \pm 1.74$ aphids/pair. The $4^{\text {th }}$ instar grub stage was most active against aphid consumption. On the $4^{\text {th }}$ instar stage the grub consumed $152.67 \pm 2.73$ aphids/pair just after molting on $1^{\text {st }}$ day of his life and continue increased in $2^{\text {nd }}$ day $(158.33 \pm 3.85$ aphids/pair) but after that continuously decreased. An average mean of consumption was $131.17 \pm 1.32$ aphids/pair. At adult stage, Coccinella septempunctata, consume average aphids 87.25 \pm 1.88 /pair. Muhammad et al., (2017) reported that $C$. septumpunctata consumed of pea aphid (77.64) was statistically high followed by 
spinach (66.27), coriander (66.14) and cabbage (61.48) aphids. Sharma and Joshi (2010) recorded that $C$. septumpunctata high feeding performance on mustard aphids $L$. erysimi than A. gossypii.

Feeding potential of Cheilomenes sexmaculata (Fabricius) on mustard aphid L. erysimi (Kalt.)

First instar larvae, the feeding potential of $1^{\text {st }}$ instar larvae was $4.11 \pm 0.49$ aphids/pair whereas it was $24.0 \pm 2.7,80.7 \pm 3.1,108.8 \pm 1.8$ and $84.2 \pm 2.6$ for second, third, fourth instars and adult stage (Fig. 1b). Day wise feeding habit of different life history stages of $C$. sexmaculata was given in Table 1 . The $1^{\text {st }}$ instar larvae consume on $3^{\text {rd }}$ days, $2^{\text {nd }}$ instar larvae consumed maximum aphid on $4^{\text {th }}$ day, $3^{\text {rd }}$ instar consume maximum on $5^{\text {th }}$ day and $4^{\text {th }}$ instar grubs consumed maximum aphids on second day. Adult consume maximum aphids on $3^{\text {rd }}$ day. Singh et al., (2008) observed that feeding potential of grub and adult of $C$. sexmaculala was $26.82 \pm 0.59$ and $47.13 \pm 1.75$ aphids per day per individual, respectively. Bahu (2001) interpreted that, this is due to consequences more energy derived by $C$. sexmaculata after feeding the aphid. Omkar (2004) noticed that $C$. sexmaculata was feeding basis overall performance of ladybird the order of suitability of prey species was $A$. craccivora $>A$. gossypii $>R$. maidis $>M$. persicae $>U$. compositae $>L$. erysimi $>A$. nerii.

Feeding potential of Hippodamia convergens on mustard aphid L. erysimi (Kalt.)

Mean consumption pattern of $H$. convergenson is given in Fig. 1c the $4^{\text {th }}$ instar larve consumed maximum aphids followed by the adult. First instar larvae consumed maximum aphids on $3^{\text {rd }}$ day, $2^{\text {nd }}$ instar larvae consumed on $4^{\text {th }}$ day, $3^{\text {rd }}$ instar larvae consumed maximum on $3^{\text {rd }}$ day and $4^{\text {th }}$ instar larvae consumed maximum of $3^{\text {rd }}$ day and adult consumed maximum aphids on $3^{\text {rd }}$ day (Table 1). Flint and Steve (2005) reported that a single release of 100 lady beetles control 6688\% aphid control during 1994 and 1995. High controlling rate may be because of highe feeding rate (100 aphids per day) of $H$. convergens (Dreistadt and Flint, 1996).

Feeding potential of Anegleis cardoni on mustard aphid L. erysimi (Kalt.)

Daily aphid consumption of $A$. cardoni is given in Table 1. Mean feeding habit of $A$. cardoni indicates that it consumed 3.78 \pm 0.29 , $11.78 \pm 0.88, \quad 35.75 \pm 2.04, \quad 68.07 \pm 1.98$ and $56.42 \pm 1.08$ aphids/pair at $1^{\text {st }}, 2^{\text {nd }}, 3^{\text {rd }}, 4^{\text {th }}$ instar larvae and adult, respectively (Fig. 1d). Therefore, fourth instar larvae of A. cardoni may be considered the most efficient predatory stage.

Similar findings were also reported by Omkar and Kumar (2013) in the management strategies of $A$. cordoni against mustard aphid. Omkar et al., (2009) further reported that the performance of A. cardoni was preydependent and the order of suitability of the prey tested was A. gossypii $>$ A. craccivora $>$ L. erysimi. Afroze (2000) found that both larvae and adults of $A$. cardoni feed on various species of aphids present on Solanum melongena, Brevicoryne brasssicae, Brassica oleracae, Macrosiphum miscanthi, Triticum aestivum and Pisum sativum plants.

Feeding potential of Micraspis allardi on mustard aphid L. erysimi (Kalt.)

The feeding potential of $1^{\text {st }}$ instar larvae was $3.7 \pm 0.2$ aphids/pair whereas it was $11.3 \pm 1.6$, $28.6 \pm 1.6,51.9 \pm 1.3$ and $35.3 \pm 1.2$ for second, third, fourth instars and adult stage (Fig. 1e). Day wise feeding habit of different life history stages of M. allardi is given in Table 1. 
Table.1 Feeding potential of Coccinella spp. against mustard aphid, Lipaphis erysimi

\begin{tabular}{|c|c|c|c|c|c|c|c|}
\hline \multirow{2}{*}{$\begin{array}{c}\text { Larvae } \\
\text { stage }\end{array}$} & \multirow{2}{*}{$\begin{array}{l}\text { Day of } \\
\text { stage }\end{array}$} & \multicolumn{6}{|c|}{ Mean of consumed mustard Aphid, Lipaphis erysimi (Mean \pm SEM)/pair } \\
\hline & & $\begin{array}{c}\text { Coccinella } \\
\text { septempunctata }\end{array}$ & $\begin{array}{l}\text { Cheilomenus } \\
\text { sexmaculata }\end{array}$ & $\begin{array}{c}\text { Hippodamia } \\
\text { variegate }\end{array}$ & $\begin{array}{c}\text { Anegleis } \\
\text { cardoni }\end{array}$ & $\begin{array}{c}\text { Micraspis } \\
\text { allardi }\end{array}$ & Illeis cincta \\
\hline \multirow{3}{*}{$\begin{array}{l}1^{\text {st }} \\
\text { Instar }\end{array}$} & $1^{\mathrm{st}}$ & $3.00 \pm 0.58$ & $3.00 \pm 0.58$ & $3.00 \pm 0.58$ & $2.33 \pm 0.33$ & $2.67 \pm 0.33$ & $1.67 \pm 0.33$ \\
\hline & $2^{\text {nd }}$ & $4.00 \pm 0.58$ & $4.33 \pm 0.33$ & $3.67 \pm 0.88$ & $4.33 \pm 0.33$ & $3.67 \pm 0.33$ & $2.33 \pm 0.33$ \\
\hline & $3^{\mathrm{rd}}$ & $6.00 \pm 0.58$ & $5.00 \pm 0.58$ & $5.00 \pm 0.58$ & $5.33 \pm 0.33$ & $4.67 \pm 0.33$ & $2.33 \pm 0.33$ \\
\hline \multirow{4}{*}{$\begin{array}{l}2^{\text {nd }} \\
\text { Instar }\end{array}$} & $1^{\text {st }}$ & $27.00 \pm 1.53$ & $10.33 \pm 0.88$ & $12.33 \pm 1.20$ & $8.00 \pm 0.58$ & $6.67 \pm 1.20$ & $5.67 \pm 0.33$ \\
\hline & $2^{\text {nd }}$ & $34.33 \pm 1.20$ & $23.00 \pm 3.79$ & $19.00 \pm 0.58$ & $11.67 \pm 1.20$ & $11.00 \pm 1.53$ & $6.33 \pm 0.88$ \\
\hline & $3^{\text {rd }}$ & $34.33 \pm 1.45$ & $30.67 \pm 4.26$ & $25.33 \pm 1.20$ & $15.67 \pm 0.88$ & $16.33 \pm 2.03$ & $8.00 \pm 0.58$ \\
\hline & $4^{\text {th }}$ & $24.00 \pm 3.47$ & $32.00 \pm 4.17$ & $27.67 \pm 0.67$ & - & - & - \\
\hline \multirow{4}{*}{$\begin{array}{l}3^{\text {rd }} \\
\text { Instar }\end{array}$} & $1^{\text {st }}$ & $69.33 \pm 0.88$ & $71.00 \pm 1.16$ & $42.33 \pm 2.85$ & $30.67 \pm 1.77$ & $23.67 \pm 1.20$ & $13.33 \pm 0.88$ \\
\hline & $2^{\text {nd }}$ & $85.00 \pm 3.47$ & $90.67 \pm 4.67$ & $56.67 \pm 2.97$ & $34.67 \pm 1.20$ & $25.67 \pm 1.20$ & $16.00 \pm 0.58$ \\
\hline & $3^{\text {rd }}$ & $97.33 \pm 0.88$ & $105.00 \pm 2.31$ & $56.67 \pm 2.61$ & $37.00 \pm 1.53$ & $30.67 \pm 1.77$ & $20.33 \pm 0.88$ \\
\hline & $4^{\text {th }}$ & $107.33 \pm 2.91$ & $56.00 \pm 4.17$ & $33.00 \pm 2.65$ & $40.67 \pm 3.76$ & $34.33 \pm 2.03$ & $27.00 \pm 1.16$ \\
\hline \multirow{6}{*}{$\begin{array}{l}4^{\text {th }} \\
\text { Instar }\end{array}$} & $1^{\text {st }}$ & $152.67 \pm 2.73$ & $116.33 \pm 1.77$ & $67.33 \pm 5.46$ & $57.67 \pm 1.45$ & $46.33 \pm 1.77$ & $33.00 \pm 3.06$ \\
\hline & $2^{\text {nd }}$ & $158.33 \pm 3.85$ & $121.33 \pm 1.77$ & $101.33 \pm 4.10$ & $64.00 \pm 2.52$ & $51.00 \pm 1.16$ & $36.67 \pm 1.45$ \\
\hline & $3^{\text {rd }}$ & $145.67 \pm 4.10$ & $121.00 \pm 3.22$ & $108.00 \pm 1.53$ & $70.00 \pm 1.16$ & $52.66 \pm 0.58$ & $39.67 \pm 1.20$ \\
\hline & $4^{\text {th }}$ & $126.00 \pm 3.22$ & $103.00 \pm 2.08$ & $103.00 \pm 2.08$ & $75.33 \pm 2.34$ & $55.33 \pm 2.19$ & $44.00 \pm 2.08$ \\
\hline & $5^{\text {th }}$ & $111.33 \pm 6.75$ & $105.33 \pm 2.41$ & $92.67 \pm 3.29$ & $73.33 \pm 2.41$ & $54.33 \pm 0.88$ & - \\
\hline & $6^{\text {th }}$ & $93.00 \pm 3.61$ & $86.00 \pm 4.36$ & $82.33 \pm 1.20$ & - & - & - \\
\hline \multirow[t]{4}{*}{ Adult } & $1^{\text {st }}$ & $69.33 \pm 0.88$ & $69.33 \pm 6.39$ & $60.67 \pm 2.03$ & $56.33 \pm 3.29$ & $35.00 \pm 2.08$ & $24.33 \pm 2.03$ \\
\hline & $2^{\text {nd }}$ & $93.00 \pm 2.65$ & $90.33 \pm 2.03$ & $77.33 \pm 3.29$ & $62.00 \pm 2.08$ & $32.00 \pm 1.16$ & $26.33 \pm 1.77$ \\
\hline & $3^{\text {rd }}$ & $95.33 \pm 3.29$ & $93.67 \pm 2.41$ & $87.00 \pm 2.31$ & $56.33 \pm 2.03$ & $36.67 \pm 1.77$ & $31.67 \pm 1.20$ \\
\hline & $4^{\text {th }}$ & $91.33 \pm 2.03$ & $83.33 \pm 0.67$ & $42.33 \pm 2.41$ & $51.00 \pm 0.58$ & $37.67 \pm 1.86$ & $36.00 \pm 4.17$ \\
\hline
\end{tabular}


Fig.1 Mean consumption rate of different instar larvae and adults of (a) $C$. septempunctata,

(b) C. sexmaculata, (c) H. variegate, (d) A. cardoni, (e) M. allardi and

(f) I. cincta on mustard aphid, L. erysimi

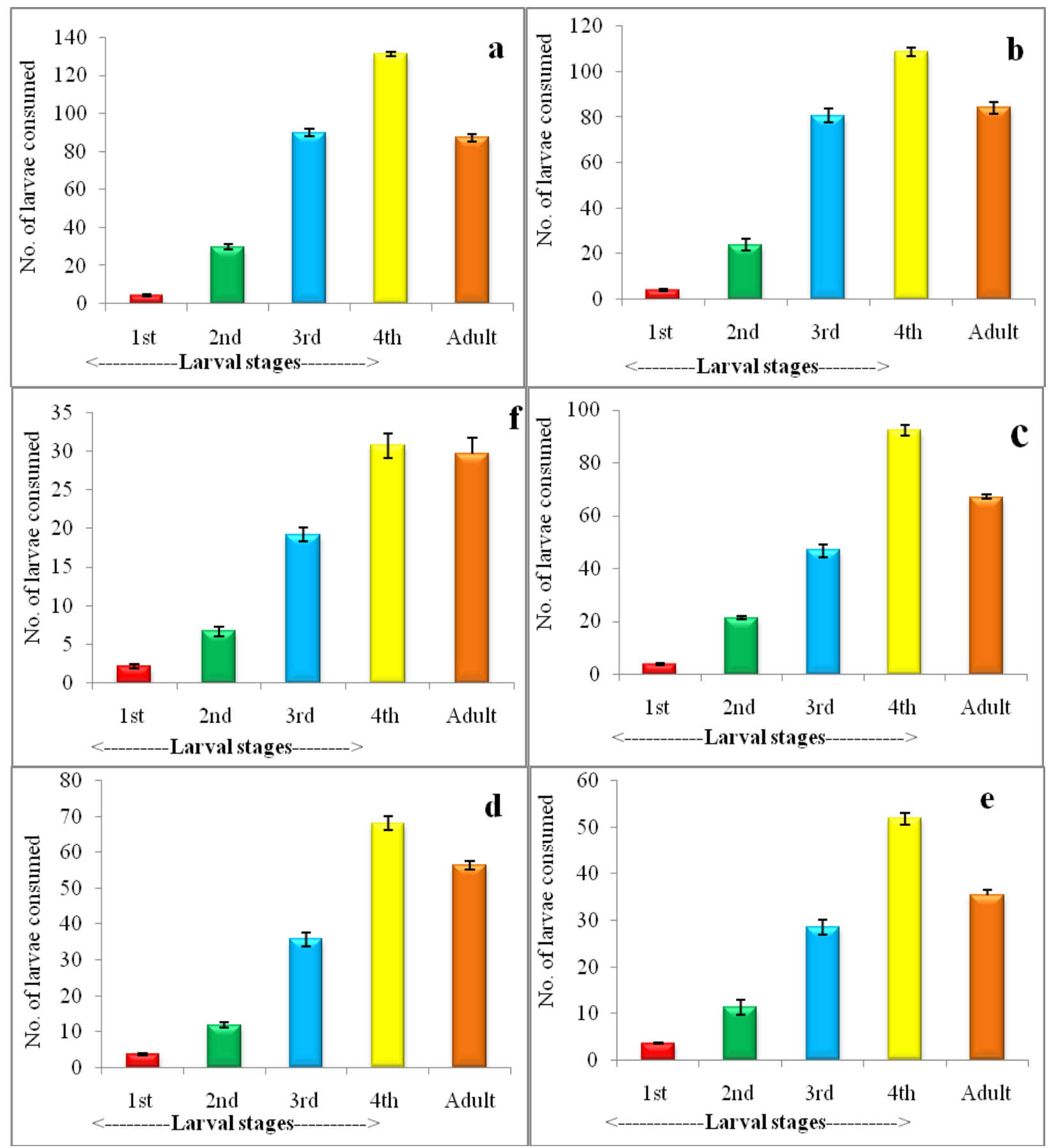

The $1^{\text {st }}$ instar larvae consume on $3^{\text {rd }}$ days, $2^{\text {nd }}$ instar larvae consumed maximum aphid on $3^{\text {rd }}$ day, $3^{\text {rd }}$ instar consume maximum on $4^{\text {th }}$ day and $4^{\text {th }}$ instar grubs consumed maximum aphids on $4^{\text {th }}$ day. Adult consume maximum aphids on $4^{\text {th }}$ day. Omkar et al., (2005) was reported that the feeding potential of $M$. allardi was low against L. erysimi. 
Feeding potential of Illeis cincta on mustard aphid L. erysimi (Kalt.)

Mean consumption pattern of $I$. cincta is given in Fig. 1f. The $4^{\text {th }}$ instar larvae consumed maximum aphids followed by the adult. First instar larvae consumed maximum aphids on $2^{\text {nd }}$ day, $2^{\text {nd }}$ instar larvae consumed on $3^{\text {rd }}$ day, $3^{\text {rd }}, 4^{\text {th }}$ instar larvae and adult consumed maximum on $4^{\text {th }}$ day (Table 1 ).

A. cardoni, M. allardi and I. cincta completes their $2^{\text {nd }}, 4^{\text {th }}$ instar larval stages earlier on compression with other study species.

The study reveals that larval period of $I$. cincta was the least (14 days_followed by M. allardi iand A. caroni (15 days). The aphid consumption increased with the xhange in the larval life cycle traits and was highest at $4^{\text {th }}$ instar larvae followed by the adults and $1^{\text {st }}$ instar larvae consume the least aphids in all the studies species.

This may be related to the life span of the larval stages. The $4^{\text {th }}$ instar larvae complete the life stadium in 5 or 6 days whereas $1^{\text {st }}$ instar completes in 3 days. The study also indicates that most predominant predatory species of beetle on mustard aphid was $C$. septempunctata consume followed by $C$. sexmacuata. On the basis of the results it may be concluded that $C$. septempunctata can be used as a bio-control agents for the mustard aphids in the Dehradun region of the India.

\section{Acknowledgement}

I am highly thankful to the Chairman, DBS College of Agriculture and Allied Science, Selaqui, Dehradun, Uttrakhand for partially supported to carry out the research work. My thankfulness also goes to Principal and other staff members of the college, who provided insight and expertise that greatly assisted the research.

\section{References}

Afroze S. 2000. Bioecology of the coccinellid Anegleis cardoni (Weise) (Coleoptera: Coccinellidae), an important predators of aphids, coccids and pseudococcids. $J$. Entom. Rese. 24:55-62.

Babu, A. 2001. Predatory potential and life parameters of Cheilomenus [Cheilomenes] (=Menochilus) sexmaculata (F.) (Coleoptera: Coccinellidae) in relation to energetics of Aphis gossypii Glover (Homoptera: Aphididae). Zoological Record Entomon., 26(1): 29-36.

Dreistadt, S.H., Flint, M.L., 1996. Melon aphid (Homoptera: Aphididae) control by inundative convergent lady beetle (Coleoptera: Coccinellidae) release on chrysanthemum. Environ. Entmol, 25:688-697.

Hawkeswood, T. 1987. Beetles of Australia. Augus and Roberston, Sydney, Australia.

Joshi, P.C. and Sharma, P.K. 2008. First Records of Coccinellid Beetles (Coccinellidae) from the Haridwar, (Uttarakhand), India. The Natural History Journal of Chulalongkorn University, 8(2): 157-167.

Majerus, M. E. N. 1994. Lady birds. Harper Collins, London, 359 pp.

Mary Louise Flint and Steve H. Dreistadt 2005. Interactions among convergent lady beetle (Hippodamia convergens) releases, aphid populations, and rose cultivar. Biological Control.34: 38-46.

Muhammad A., Hafiz A. A. K., Faisal H., Ravaid S. and Naeem I. 2017. Predatory Potential of Coccinella septempunctata L. against Four Aphid Species. Pakistan Journal Zoology, 49(2):623-627.

Omkar and Kumar G. 2013. Responses of an aphidophagous ladybird beetle, Anegleis cardoni, to varying densities of Aphis gossypii. J. Insect Sci., 13:13:24. 
Omkar, Gyanendra Kumar and Jyotsna Sahu 2009. Performance of a predatory ladybird beetle, Anegleis cardoni (Coleoptera: Coccinellidae) on three aphid species. Eur. J. Entomol., 106 (4): 565-572.

Omkar, Pervez A. and Singh S.K. 2005. Development and immature survival of two aphidophagous ladybirds, Coelophora biplagiata and Micraspis discolor. Insect Science. 12: 375-379.

Omkar, R. B.; Bind, 2004. Prey Quality Dependent Growth, Development and Reproduction of a Biocontrol Agent, Cheilomenes sexmaculata (Fabricius) (Coleoptera: Coccinellidae). Bio. Scie. \& Tech., 14(7):665-673.

Omkar. Bind, RB.1996. Record of aphidsnatural enemies complex of Uttar Pradesh. J. Adva. Zool., 17(1): 44-48.

Omkar. Pervez, Ahmad 1999. New record of coccinellids from Uttar Pradesh. Journal of Advanced Zoology; 20(2): $106-112$.

Poorani, J. 2002. An annolated checklist of the Cocinellidae (Coleoptera) (excluding Epilachninae) of the India sub-region. Oriental Insect, 36: 307383.

Pushpendra K. Sharma and Prakash C. Joshi 2010. Feeding Potential of Seven Spotted Ladybeetle, Coccinella septumpunctata (Linnaeus) on Mustard Aphid, Lipaphis erysimi (Kaltenbach) and Cotton Aphid, Aphis gossypii (Glover). Nature and Science, 8(12), pp 198-202.

Sharma, P.K. and Joshi, P.C. 2010. Feeding potential of seven spotted lady beetle, Cocinella septempunctata (L.) on mustard aphid Lipaphis erysimi (K.) and cotton aphid Aphis gossypii (Glov.). Nature and Science, 8(12): 198-202.

Singh, Y.P., H.P. Meghwal and S.P. Singh 2008. Biology and Feeding Potential of Cheilomenes sexmaculata Fabricius (Coleoptera: Coccinellidae) on Mustard Aphid. Annals of Arid Zone, 47(2): 185190.

\section{How to cite this article:}

Sundar Pal and Jitendra Bhatt. 2018. Feeding Efficiency of Six Beetle Species against Mustard Aphid, Lipaphis erysimi (Kalt.) in Uttarakhand, India. Int.J.Curr.Microbiol.App.Sci. 7(04): 1970-1976. doi: https://doi.org/10.20546/ijcmas.2018.704.226 